\title{
The Research Results in the Area Of Environmental Taxation of Manufacturing Business En- tities in the Czech Republic
}

\section{Zdeněk Hruška, Lilia Dvořáková}

Faculty of Economics, Department of Finance and Accounting, University of West Bohemia.

Husova 11, 30614 Plzeň. Česká republika. E-mail: hruskaz@kfu.zcu.cz, ldvorako@kfu.zcu.cz

The paper deals with the current topic of environmental taxes on the level of the Czech Republic. The urgency of the topic is highlighted by the dynamic international development of environmental taxation and continuous unification within the European Union. Environmental taxes affect the final consumers of solid fuels, electricity and natural gas and some other gases. The paper researches the impact of environmental taxes on a selected group of manufacturing business entities which are largely consumers of products taxed by environmental taxes. This type of taxes represents a part of corporate environmental costs and as such it is necessary to manage these costs. At first the paper examines the influence of environmental taxes on the enterprise performance after their introduction into the Czech tax system in 2008 and then there are proposed the indicators for monitoring and management of environmental taxes as a part of the enterprise costs. The influence of environmental taxes on business entities is researched by the profit and loss report item "consumption of material and energy", the economic result, rentability of assets indicator and also by the proposed material and energy costs rentability indicator. Further there are proposed two other ratio indicators for environmental taxes monitoring within the corporate costs which can also serve as one of the criteria for investment decision-making of an enterprise. For the correct quantification of the proposed indicators a reference accounting timetable is drafted which includes the environmental taxes analytical evidence and their integration into the corporate accounting.

Keywords: costs management, environmental tax, environmental costs, enterprise performance introduction, manufacturing business entities

\section{References}

[1] BÁRCENA-RUIZ, J. C. (2006). Environmental Taxes and First-Mover Advantages. Environmental \& Resource Economics. 35(1), pp. 19 - 39.

[2] BŘEZINA, J. (2009). Zavedení ekologických daní v ČR. Účetnictví, daně a právo v zemědělství. 2(10).

[3] EKINS, P., SPECK, S. (2011). Environmental Tax Reform (ETR). A policy for Green Growth. New York: Oxford University Press Inc, $416 \mathrm{p}$.

[4] GRÜNWALD, R., HOLEČKOVÁ, J. (2009). Finančni analýza a plánováni podniku. Praha: Ekopress, s.r.o., 318 p.

[5] HRUŠKA, Z., DVOŘÁKOVÁ, L. (2014). Sledování environmentálních daní v rámci nákladů podnikatelských subjektů. Trendy v podnikáni. 4(4), pp. $12-19$.

[6] Klasifikace ekonomických činností (CZ-NACE). (2014). In Český statistický úřad. (2014) Retrieved December 28, 2014, from http://www.czso.cz/csu/klasifik.nsf/i/klasifikace_ekonomickych_cinnosti_(cz_nace).

[7] KUBÁtOVÁ, K. (2010). Daňová teorie a politika. Praha: Wolters Kluwer, 276 p.

[8] POPESKO, B. (2009). Moderní metody ř́zení nákladi̊. Praha: Grada Publishing a.s., 231 p.

[9] VANĚČEK, V. (1995). Environmentální podnikové účetnictví. Retrieved December 30, 2014, from http://www.czp.cuni.cz/knihovna/undp/modra/M13_Vanecek.htm.

[10]Zákon č. 261/2007 Sb., o stabilizaci veřejných rozpočtů. In: Sbírka zákonů. 19. 9. 2007.

[11]Zákon č. 563/1991 Sb., o účetnictví. In: Sbírka zákonů. 12. 12. 1991.

[12]ZIMMERMANNOVÁ, J. (2011). Environmentální náklady podniku spojené s plněním legislativy v České republice. Acta Oeconomica Pragensia. 19(5), pp. 48 - 67.

[13]ŽIŽLAVSKÝ, O. (2014). Faktory úspěchu inovací. Trendy v podnikání. 4(1), pp. 24 - 30.

[14]ZUNK, M. B., SOOS, J., UITZ, I., DENGER, A., BADER, M. (2013). Life Cycle Management Tools: Explorative Findings and Managerial Implications. Manufacturing Technology, 4(13), pp. 580 - 586. 